\title{
Ectoine Production from Biogas in Waste Treatment Facilities: A Techno-Economic and Sensitivity Analysis
}

\author{
Víctor Pérez, Jose Luis Moltó, Raquel Lebrero, and Raúl Muñoz*
}

Cite This: ACS Sustainable Chem. Eng. 2021, 9, 17371-17380

Read Online

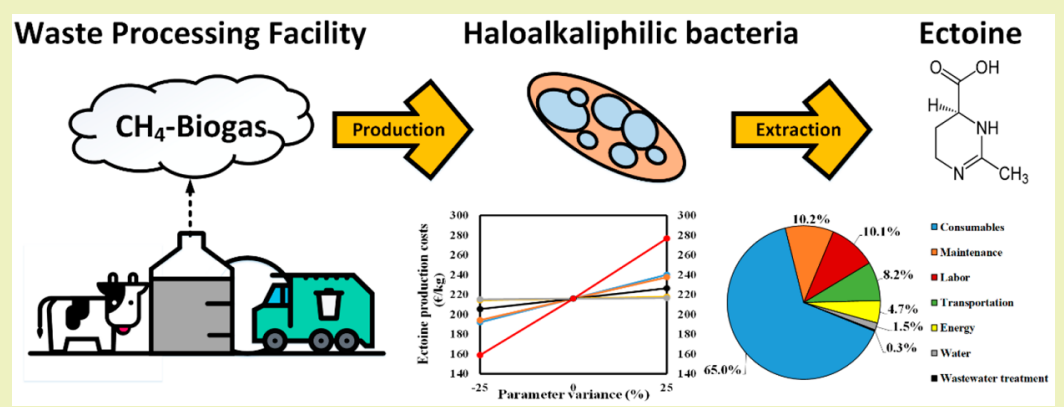

ABSTRACT: The capacity of haloalkaliphilic methanotrophic bacteria to synthesize ectoine from $\mathrm{CH}_{4}$-biogas represents an opportunity for waste treatment plants to improve their economic revenues and align their processes to the incoming circular economy directives. A techno-economic and sensitivity analysis for the bioconversion of biogas into $10 \mathrm{t}$ ectoine $\cdot \mathrm{y}^{-1}$ was conducted in two stages: (I) bioconversion of $\mathrm{CH}_{4}$ into ectoine in a bubble column bioreactor and (II) ectoine purification via ion exchange chromatography. The techno-economic analysis showed high investment $\left(4.2 \mathrm{M} €\right.$ ) and operational costs $\left(1.4 \mathrm{M} € \cdot \mathrm{y}^{-1}\right)$. However, the high margin between the ectoine market value $\left(600-1000 € \cdot \mathrm{kg}^{-1}\right)$ and the estimated ectoine production costs $\left(214 € \cdot \mathrm{kg}^{-1}\right)$ resulted in a high profitability for the process, with a net present value evaluated at 20 years $\left(\mathrm{NPV}_{20}\right)$ of $33.6 \mathrm{M} €$. The cost sensitivity analysis conducted revealed a great influence of equipment and consumable costs on the ectoine production costs. In contrast to alternative biogas valorization into heat and electricity or into low added-value bioproducts, biogas bioconversion into ectoine exhibited high robustness toward changes in energy, water, transportation, and labor costs. The worst- and best-case scenarios evaluated showed ectoine break-even prices ranging from 158 to $275 € \cdot \mathrm{kg}^{-1}, \sim 3-6$ times lower than the current industrial ectoine market value.

KEYWORDS: Biogas valorization, Biorefinery, Ectoine, Haloalkaliphilic methanotrophic bacteria, Techno-economic assessment, Sensitivity analysis

\section{INTRODUCTION}

In the past decade, the construction of biogas plants associated with the treatment of wastewater, agro-industrial residues, and urban waste in Europe has grown exponentially from 6227 in 2011 to 18943 operative biogas plants in 2019. ${ }^{1}$ The main motivation behind this growth has been the production of renewable electricity from biogas, which has increased concomitantly from 66 TWh in 2011 to 167 TWh in 2019 in Europe. ${ }^{1}$ Nevertheless, in the past few years, the high competition in the European renewable energy market combined with the rapid drop in production costs of competing renewable energies $(-82 \%$ and $-39 \%$ drop between 2010 and 2019 for solar and wind energies, respectively) and the elevated capital (400-1100 €.kW ${ }^{-1}$ ) and operational costs $\left(0.01-0.02 € \cdot \mathrm{kWh}^{-1}\right)$ of electricity and heat cogeneration ( $\mathrm{CHP}$ ) systems have stalled the growth of this biogas valorization alternative, with a marginal increase of $4.3 \%$ in the period $2015-2019 .{ }^{1-4}$ In this regard, a recent techno-economic analysis has demonstrated the excessive dependence of biogas-to-energy facilities on the extension of fiscal incentives. ${ }^{5}$ However, fiscal exemptions such as feed in tariffs or carbon credits are no longer available for renewable energy production as policy-makers and governments have recently focused their attention on the transformation of current waste treatment plants into circular biorefineries, able to produce marketable products from waste streams.

In this context, alternative biogas valorization pathways such as the production of biomethane (renewable natural gas) and platform chemicals such as methanol, polyhydroxyalkanoates

Received: October 5, 2021

Revised: December 9, 2021

Published: December 15, 2021 


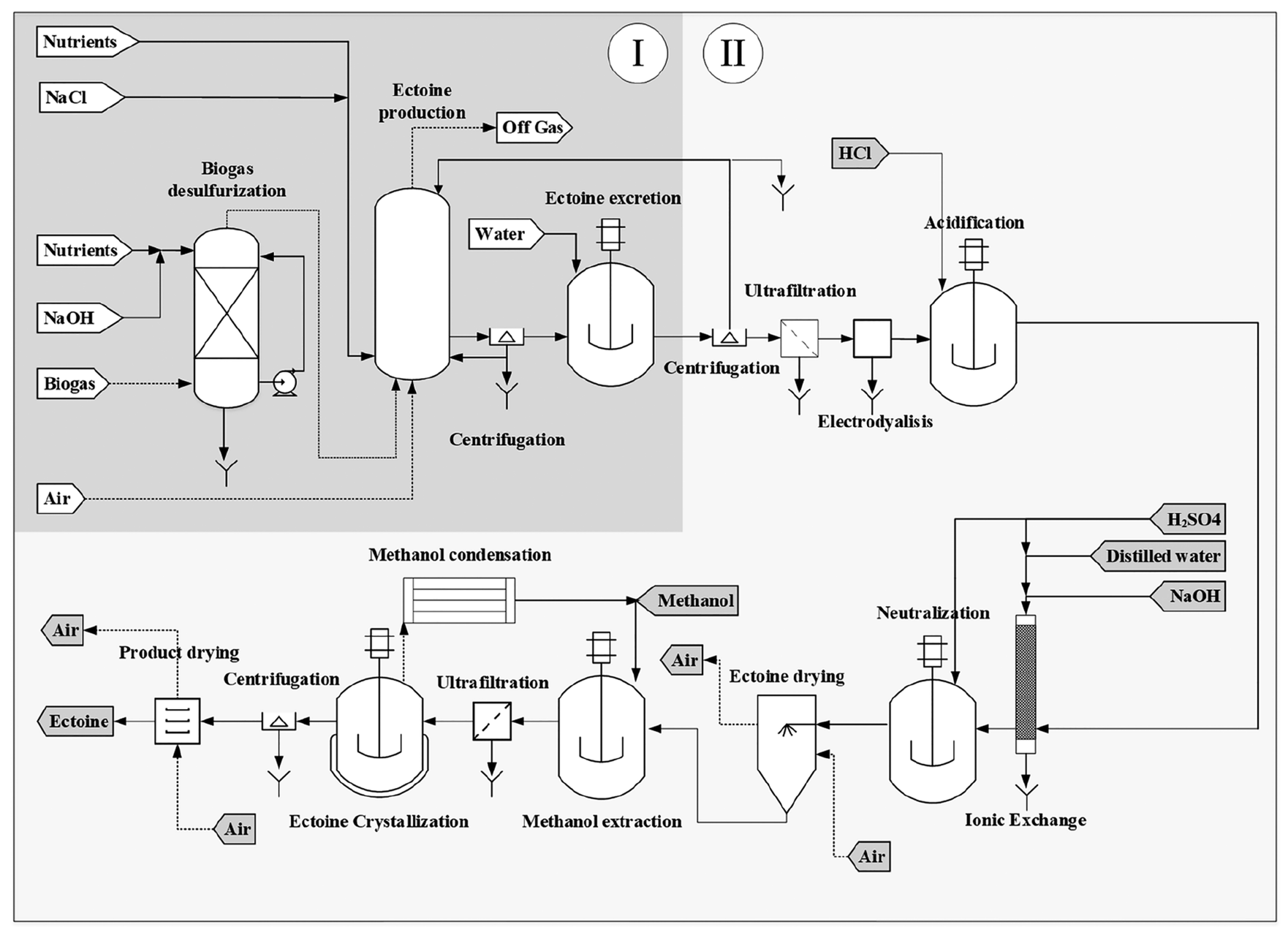

Figure 1. Simplified process flow diagram for $\mathrm{CH}_{4}$-biogas bioconversion into ectoine. The process was divided into two different stages: (I) ectoine biosynthesis from biogas and (II) ectoine extraction and purification.

(PHA), or single cell protein from biogas components (mainly methane $\left(\mathrm{CH}_{4}\right)$ and carbon dioxide $\left(\mathrm{CO}_{2}\right)$ ) have rapidly developed and attracted significant research efforts from academia and industry. ${ }^{6,7}$ The transition from the current linear anaerobic digestion plants to next-generation circular waste biorefineries might help in adapting the processes to the increasingly restrictive environmental policies, in line with the European Green New Deal and Circular Economy Directives, while boosting the economic feasibility of waste treatment plants by reducing the influence of the fluctuating energy market on the final economic balance of the plant. ${ }^{8,9}$ The best example of this changing trend is the increasing number of public-private initiatives aimed at demonstrating at semiindustrial scale the technical, economic, and environmental feasibility of waste biorefineries. Particularly, different European consortia have included in their biorefinery concepts the biological transformation of biogas into: biomethane (INCOVER and URBIOFIN), PHA (URBIOFIN), biostimulants (CIRCULAR BIOCARBON) or ectoine (DEEP PURPLE). These demo-scale projects, together with an extensive investigation work at laboratory scale, have consistently evidenced the high economic and environmental potential of these technologies at industrial scale. ${ }^{7,9,10}$

Today, $\mathrm{CH}_{4}$-based bioproducts struggle to compete in price against their oil-based or sugar-based counterparts mainly due to the high energy demand required for $\mathrm{CH}_{4}$ and oxygen $\left(\mathrm{O}_{2}\right)$ gas-liquid mass transfer and the low productivity of methanotrophic fermentation processes. ${ }^{11,12}$ These technological barriers are especially relevant for the production of low added-value products such as PHA (4-20 € $\left.\cdot \mathrm{kg}^{-1}\right)$, single cell protein $\left(0.5-1 € \cdot \mathrm{kg}^{-1}\right)$, or methanol $\left(0.5-2 € \cdot \mathrm{kg}^{-1}\right)$, whose operational costs often exceed their market selling prices, thus hindering their production in waste treatment facilities. ${ }^{8}$

However, the recent discovery of the capacity of haloalkaliphilic methanotrophic bacteria to accumulate high amounts of ectoine (up to $230 \mathrm{mg}$ ectoine.g biomass ${ }^{-1}$ ), a bacterial osmotic protector with a high industrial interest in the cosmetic industry, has opened the door to the production of high added-value products from biogas. ${ }^{13,14}$ Ectoine, with a market price ranging from 600 to $1000 € \cdot \mathrm{kg}^{-1}$ and an annual demand in the range of $20 \mathrm{t}$, has been traditionally produced via sugar-based fermentation with Halomonas elongate in a process called "bio-milking". ${ }^{15,16}$ This biotechnological process presents high production costs due to the use of high quality carbon sources (e.g., glucose) and sterile conditions, and an expensive downstream processing. ${ }^{17,18}$ Therefore, the use of $\mathrm{CH}_{4}$-biogas as a widely available and low-cost substrate might contribute to the reduction of ectoine production costs and can be regarded as an opportunity for waste management companies to invest in circular economy concepts. However, the techno-economic feasibility of upscaling the production 
process and the influence of commodity prices and capital costs on biogas-based ectoine production remain unknown.

In this study, a techno-economic evaluation of ectoine production from biogas was conducted, with special attention to the production of ectoine in a bubble column bioreactors (BCB) and to the ectoine purification process via ion exchange chromatography (IEX). In addition, a sensitivity analysis was performed to assess the influence of labor and transportation costs, commodity prices, capital costs, and the interest and tax rates on the final market price of ectoine.

To the best of the authors knowledge, this study constitutes the first comprehensive techno-economic and sensitivity analysis focusing on the production of high added-value products from biogas.

\section{MATERIALS AND METHODS}

All calculations were performed in Excel Sheets and have been corroborated with global and elemental mass balances. Mass and energy balances were performed assuming an ideal gas behavior given the low pressure and temperatures of the streams. Mass and energy balances as well as stream tables can be consulted in the Supporting Information (SI Figures S1-S3; Tables S1-S7). A detailed compilation of the equipment design calculation has been included in the SI. The text includes all the relevant parameters for a reliable reproduction of the process design, economic calculations, and sensitivity analysis herein performed.

Process Design. A waste treatment plant with a continuous biogas production of $1000 \mathrm{~N} \mathrm{~m}^{3} \cdot \mathrm{h}^{-1}$ was selected as a model centralized anaerobic digestion plant constructed in medium and large municipalities. In this type of plant, $40 \%$ of the total biogas production is typically used for internal energy provision via CHP and therefore, the remaining $600 \mathrm{~N} \mathrm{~m}^{3} \cdot \mathrm{h}^{-1}$ are available to be further valorized. In this study, $67 \mathrm{~N} \mathrm{~m}^{3} \cdot \mathrm{h}^{-1}$ of the remaining biogas stream was considered as a carbon source for the production of $10 \mathrm{t} \cdot \mathrm{y}^{-1}$ ectoine. The process was divided into two different stages: (I) ectoine biosynthesis from biogas and (II) ectoine extraction and purification (Figure 1). A more detailed process flow diagram, including all the auxiliary equipment, is included in the SI (Figures S1-S3).

Ectoine Biosynthesis from Biogas. Prior to biogas valorization into ectoine, a biogas desulfurization stage was designed for preventing corrosion in downstream piping and equipment. Biological anoxic desulfurization was selected as the model technology given its low operational costs, reduced environmental impact, and high $\mathrm{H}_{2} \mathrm{~S}$ removal efficiency $\left(\mathrm{H}_{2} \mathrm{~S}-\mathrm{RE}\right) .{ }^{19}$ In this process, sulfur-oxidizing bacteria use nitrate $\left(\mathrm{NO}_{3}{ }^{-}\right)$instead of oxygen as the electron acceptor for the oxidation of $\mathrm{H}_{2} \mathrm{~S}$ into $\mathrm{SO}_{4}{ }^{2-20} \cdot{ }^{20} 4 \mathrm{~m}^{3}$ (height, $\mathrm{H}=$ $3.1 \mathrm{~m}$ and diameter, $D)=1.3 \mathrm{~m}$ ) biotrickling filter packed with a mixture of activated carbon and inert material was designed with an empty bed residence time (EBRT) of $3 \mathrm{~min}$ and an $\mathrm{H}_{2} \mathrm{~S}-\mathrm{RE}$ of $99 \%$. A molar nitrogen-to-sulfur ratio of 2.5 was guaranteed by continuously spraying the packing media with a sodium nitrate $\left(\mathrm{NaNO}_{3}\right)$ and micronutrients solution at a trickling liquid velocity of $10 \mathrm{~m} \cdot \mathrm{h}^{-1} \cdot{ }^{21}$ A constant $\mathrm{pH}$ of 7 was maintained via addition of $5 \mathrm{M}$ sodium hydroxide solution $(\mathrm{NaOH})$.

A mixed culture of haloalkaliphilic methanotrophic bacteria was selected for the production of ectoine from $\mathrm{CH}_{4}$-biogas. The use of mixed methanotrophic cultures has been demonstrated to be an efficient method supporting long-term operation and process robustness, given its inherent prevention of culture contamination. ${ }^{22}$ Despite the fact that the bacterial population structure might be highly variable depending on the inoculum and the culture and environmental conditions, previous work at lab-scale under nonsterile conditions has shown a predominance of ectoine producing methanotrophs such as Methylomicrobium buryatense and Methylomicrobium japanense species in these mixed cultures. ${ }^{23} \mathrm{~A} \mathrm{NaCl}$ concentration of $6 \% \mathrm{w} \cdot \mathrm{w}^{-1}$ has been reported in the literature as the optimal salinity for the accumulation of ectoine in haloalkaliphilic methanotrophic cultures. ${ }^{23,24}$ The bioreactor was operated under continuous mode at a dilution rate of $0.4 \mathrm{~d}^{-1}$. A mineral medium solution containing $41.0 \mathrm{~g} \mathrm{NaNO}_{3} \cdot \mathrm{L}^{-1}, 82.5 \mathrm{~g} \mathrm{NaCl} \cdot \mathrm{L}^{-1}$, and trace concentrations of micronutrients was continuously added to support haloalkaliphilic methanotrophic bacteria growth and ectoine synthesis. Recent studies have shown that high copper concentrations promote ectoine excretion from the cell in haloalkaliphilic bacteria. ${ }^{24}$ In this study, ectoine excretion under high salinity conditions was considered negligible, given the trace levels of copper in the mineral medium. A tungsten concentration of $0.07 \mathrm{mg} \cdot \mathrm{L}^{-1}$ was supplemented to the liquid medium in order to prevent the formation of formic acid, which typically exhibits a significant inhibitory effect on the elimination capacity of methane $\left(\mathrm{CH}_{4}\right.$-EC) ${ }^{25}$ A specific biomass production yield of $0.4 \mathrm{~g}$ biomass $\cdot \mathrm{g} \mathrm{CH}_{4}^{-1}$ and an ectoine accumulation of $70 \mathrm{mg}$ ectoine. $\mathrm{g}$ biomass $^{-1}$ were chosen according to previous results at laboratory scale. ${ }^{23}$ The stoichiometric formulas of biomass and ectoine were $\mathrm{C}_{4} \mathrm{H}_{8} \mathrm{O}_{2} \mathrm{~N}$ and $\mathrm{C}_{6} \mathrm{H}_{10} \mathrm{~N}_{2} \mathrm{O}_{2}$, respectively. A mineralization ratio of $0.7 \mathrm{~mol} \mathrm{CO} \cdot \mathrm{mol} \mathrm{CH}_{4}^{-1}$ and an oxygen demand of 1.5 $\mathrm{mol} \mathrm{O}_{2} \cdot \mathrm{mol} \mathrm{CH}_{4}^{-1}$ were used according to eqs $1-3$ :

$$
\begin{aligned}
& \text { biomass production: } \mathrm{CH}_{4}+\frac{3}{8} \mathrm{O}_{2}+\frac{1}{4} \mathrm{NO}_{3}^{-} \rightarrow \frac{1}{4} \mathrm{C}_{4} \mathrm{H}_{8} \mathrm{O}_{2} \mathrm{~N}+\mathrm{H}_{2} \mathrm{O} \\
& \text { ectoine production: } \mathrm{CH}_{4}+\frac{1}{4} \mathrm{O}_{2}+\frac{1}{3} \mathrm{NO}_{3}^{-} \rightarrow \frac{7}{6} \mathrm{H}_{2} \mathrm{O}+\frac{1}{6} \mathrm{C}_{6} \mathrm{H}_{10} \mathrm{~N}_{2} \mathrm{O}_{2}
\end{aligned}
$$

mineralization: $\mathrm{CH}_{4}+2 \mathrm{O}_{2} \rightarrow 2 \mathrm{H}_{2} \mathrm{O}+\mathrm{CO}_{2}$

A BCB with a total volume of $196 \mathrm{~m}^{3}(H=30 \mathrm{~m} ; D=2.9 \mathrm{~m})$ and a gas EBRT of $1.2 \mathrm{~h}$ was calculated as the model bioreactor to support an effective gas-liquid mass transfer of $\mathrm{CH}_{4}$ (biogas) and $\mathrm{O}_{2}$ (air). The calculation process has been detailed in the SI. Perfect mixing in the $\mathrm{BCB}$ was assumed given the high turbulence induced by the high biogas/air gas flow and the high height-to-diameter ratio $(H / D)(10)$ of the bioreactor, resulting in a $\mathrm{CH}_{4}$ removal efficiency $\left(\mathrm{CH}_{4}-\mathrm{RE}\right)$ of $90 \%$. $\mathrm{CH}_{4}$ - $\mathrm{RE}$ was defined as the percentage of methane being eliminated in the bioreactor by the action of methanotrophic bacteria according to eq 4 , where $Q$ stands for the volumetric gas flow in the inlet and outlet streams, and $Y_{\mathrm{CH} 4}$ stands for the molar fraction of $\mathrm{CH}_{4}$ in the gas phase in the inlet and outlet gas streams.

$$
\mathrm{CH}_{4}-\mathrm{RE}(\%)=\frac{Q_{\text {in }} \cdot Y_{\mathrm{CH}_{4}}-Q_{\text {out }} \cdot Y_{\mathrm{CH}_{4_{\text {out }}}}}{Q_{\text {in }} \cdot Y_{\mathrm{CH}_{4}}}
$$

The calculated outlet gas composition was $1.4 / 17.1 / 79.3 / 2.1 \%$ for $\mathrm{CH}_{4} / \mathrm{CO}_{2} / \mathrm{N}_{2} / \mathrm{O}_{2}$, respectively. Therefore, further valorization of the outlet gas stream was not considered as an energy vector given the high amount of inert compounds $\left(\mathrm{N}_{2}\right.$ and $\left.\mathrm{CO}_{2}\right)$ and the concentration of $\mathrm{CH}_{4}$ and $\mathrm{O}_{2}$ below the explosion limits $\left(\mathrm{CH}_{4} \mathrm{~S}^{-}\right.$ $15 \%$ and $\left.\mathrm{O}_{2}>13 \%\right)$. Additionally, recycling the outlet stream into the bioreactor would result in a decrease in the gas-liquid gradient and a high energy cost for the recompression of the gas stream.

Previous studies on biogas valorization in BCBs have shown that $\mathrm{CH}_{4}$-EC constitutes the main biotechnological limitation given its large influence on the capital investment costs (TIC). ${ }^{7} \mathrm{CH}_{4}$-EC has been defined as the $\mathrm{CH}_{4}$ mass flow eliminated by volumetric unit of bioreactor according to eq 5 , where $Q$ stands for the inlet and outlet volumetric flow of gas streams, $Y_{\mathrm{CH} 4}$ refers to the molar fraction of $\mathrm{CH}_{4}$ in the inlet and outlet streams, and $V$ represents the liquid volume in the bioreactor.

$$
\mathrm{CH}_{4}-\mathrm{EC}=\frac{Q_{\text {in }} \cdot Y_{\mathrm{CH}_{4}}-Q_{\text {out }} \cdot Y_{\mathrm{CH}_{4_{\text {out }}}}}{V}
$$

However, to date there is not available information in the literature concerning $\mathrm{CH}_{4}$-EC in large-scale BCBs. For the purpose of this study, a $\mathrm{CH}_{4}$-EC value of $148 \mathrm{~g} \mathrm{CH}_{4} \mathrm{~m}^{-3} \mathrm{~h}^{-1}$ was extrapolated from commercial $\mathrm{BCBs}$ treating $30 \% \mathrm{v} \cdot \mathrm{v}^{-1} \mathrm{CO}$ streams, which can reach up to $1 \mathrm{~kg} \mathrm{CO} \cdot \mathrm{m}^{-3} \cdot \mathrm{h}^{-1} \cdot{ }^{26} \mathrm{~A} \mathrm{CO}$ volumetric mass transfer coefficient $\left(\mathrm{kla}_{\mathrm{CO}}\right)$ was calculated with eq 6, where CO-EC stands for the CO elimination capacity, $C_{\mathrm{CO}}$ represents the inlet $\mathrm{CO}$ gas concentration, 
$H_{\mathrm{CO}}$ refers to the dimensionless Henry's law constant of CO (29.81 at $288.15 \mathrm{~K}$ and $3.78 \mathrm{~atm}$ ), and $C_{\mathrm{LCO}}$ for the bulk aqueous $\mathrm{CO}$ concentration, considered negligible under mass transfer limitation scenarios. $^{27}$

$$
\mathrm{kla}_{\mathrm{CO}}=\frac{\mathrm{CO}-\mathrm{EC}}{\left(\frac{\mathrm{C}_{\mathrm{CO}, \text { in }}}{H_{\mathrm{CO}}}-C_{\mathrm{L}, \mathrm{CO}}\right)}
$$

The volumetric $\mathrm{CH}_{4}$ mass transfer coefficient $\left(\mathrm{CH}_{4}\right.$-kla) was calculated according to eq 7, where $V_{\mathrm{m}}$ stands for the molar volume at the normal boiling point of $\mathrm{CH}_{4}\left(35.05 \mathrm{~m}^{3} \cdot \mathrm{kg}^{-1}\right)$ and $\mathrm{CO}\left(32.74 \mathrm{~m}^{3}\right.$. $\left.\mathrm{kg}^{-1}\right) .^{28}$

$$
\frac{\mathrm{kla}_{\mathrm{CH}_{4}}}{\mathrm{kla}_{\mathrm{CO}}}=\frac{\left(\frac{1}{V_{\mathrm{m}, \mathrm{CH}}}\right)^{0.4}}{\left(\frac{1}{V_{\mathrm{m}, \mathrm{CO}}}\right)^{0.4}}
$$

$\mathrm{CH}_{4}$-EC was calculated according to eq 8 , where $\mathrm{kla}_{\mathrm{i}}$ stands for the volumetric mass transfer coefficient of substance i, $\mathrm{C}_{\mathrm{CH} 4 \text {,in }}$ stands for the inlet $\mathrm{CH}_{4}$ gas concentration, $\mathrm{H}_{\mathrm{CH} 4}$ for the dimensionless Henry's law constant of $\mathrm{CH}_{4}\left(43.03\right.$ at $288.15 \mathrm{~K}$ and $3.78 \mathrm{~atm}$ ), and $\mathrm{C}_{\mathrm{L}, \mathrm{CH} 4}$ for the bulk aqueous $\mathrm{CH}_{4}$ concentration, considered negligible under mass-transfer limitation scenarios. ${ }^{27}$

$$
\mathrm{CH}_{4}-\mathrm{EC}=\mathrm{kla}_{\mathrm{CH}_{4}} \cdot\left(\frac{\mathrm{C}_{\mathrm{CH}_{4} \text {,in }}}{\mathrm{H}_{\mathrm{CH}_{4}}}-\mathrm{C}_{\mathrm{L}, \mathrm{CH}_{4}}\right)
$$

Ectoine Extraction and Purification. Haloalkaliphilic methanotrophic bacteria containing ectoine was harvested and centrifuged to reach a biomass concentration of $200 \mathrm{~g}$ biomass $\cdot \mathrm{L}^{-1}$. An aliquot of the liquid fraction of $10 \%$ was daily wasted from the system to avoid the accumulation of secondary metabolites. The concentrated biomass stream was subjected to a hyposmotic shock in a nonsaline medium to promote the excretion of $85 \%$ of the total intracellular ectoine. ${ }^{29,30}$ The process was carried out in a $104.1 \mathrm{~L}(H=0.6 \mathrm{~m} ; D=0.5 \mathrm{~m})$ continuous stirred tank reactor (CSTR) with a hydraulic retention time (HRT) of $5 \mathrm{~min}^{26}$ Biomass containing only $15 \%$ of the initial intracellular ectoine was subsequently centrifuged to a concentration of $200 \mathrm{~g}$ biomass $\cdot \mathrm{L}^{-1}$ and recirculated to the bioreactor. A fraction of the biomass was continuously wasted to maintain an average biomass residence time of $9 \mathrm{~d}$, preventing biomass activity decay, similarly to the industrial biomilking process with Halomonas Elongate. ${ }^{11}$ The aqueous solution containing the extracted ectoine was desalinized via subsequent ultrafiltration and electrodialysis. A $58.2 \mathrm{~m}^{2}$ ultrafiltration membrane system was designed with a typical permeate flux of $15 \mathrm{~L}$. $\mathrm{m}^{-2} \cdot \mathrm{h}^{-1}$, a pressure drop of $300 \mathrm{mbar}$, and a biomass recovery of $99 \%$. Accordingly, a typical permeate flux of $45 \mathrm{~L} \cdot \mathrm{m}^{-2} \cdot \mathrm{h}^{-1}$, a pressure drop of 200 mbar, and a concentration factor of 25 were selected for desalination with a $17.5 \mathrm{~m}^{2}$ electrodialysis system.

A two-step IEX and methanol crystallization process has been identified as the most efficient and scalable method for ectoine concentration and purification, capable of providing a high recovery and purity of the product. ${ }^{18,31}$ This process was simulated in this paper with a product recovery and purity of $62 \%$ and $97 \%$, respectively. Prior to the isolation of ectoine via IEX, the liquid stream containing ectoine was acidified to $\mathrm{pH} 2$ by addition of $10 \mathrm{M}$ $\mathrm{HCl}$ in a $1.7 \mathrm{~m}^{3}(H=1.5 \mathrm{~m} ; D=1.2 \mathrm{~m})$ CSTR operated at a HRT of $1 \mathrm{~h}^{18}$ Then, the ectoine broth was pumped into a column packed with an ion-exchange resin and selectively adsorbed. A resin bed volume (BV) of $500 \mathrm{~L}(H=4 \mathrm{~m} ; D=0.4 \mathrm{~m})$ was needed to achieve an ectoine recovery of $90 \%$. A high performance ion-exchange resin $($ DOWEX 50w $\times 8)$ with an adsorbing capacity of $0.1 \mathrm{~kg}$ ectoine $\cdot \mathrm{kg}$ resin $^{-1}$ and a density of $800 \mathrm{~kg} \cdot \mathrm{m}^{3}$ was selected. ${ }^{32}$ The adsorbed ectoine was washed with $2 \mathrm{BV}$ of $98 \% \mathrm{w} \cdot \mathrm{w}^{-1} \mathrm{H}_{2} \mathrm{SO}_{4}$ and $2 \mathrm{BV}$ of distilled water to remove impurities. Finally, the ectoine was eluted with $6 \mathrm{BV}$ of $1.3 \mathrm{M} \mathrm{NaOH}$, of which $4 \mathrm{BV}$ were discarded. Subsequently, the liquid was neutralized to $\mathrm{pH} 7$ via addition of $98 \%$ $\mathrm{w} \cdot \mathrm{w}^{-1} \mathrm{H}_{2} \mathrm{SO}_{4}$ in a $40.4 \mathrm{~L}(\mathrm{H}=0.4 ; \mathrm{D}=0.3) \mathrm{CSTR}$ with an EBRT of $1 \mathrm{~h}$.

In a later step, the product was dried to a moisture content of $5 \% \mathrm{w}$. $\mathrm{w}^{-1}$ in a $400 \mathrm{~L}$ spray dryer operated at $0.3 \mathrm{~atm}$ and heated via low pressure steam ( 2 bar). The spray drying system was designed with a specific evaporation rate of $100 \mathrm{~kg}$ water $\cdot \mathrm{m}^{-3} \cdot \mathrm{h}^{-1}$. Prior to ectoine crystallization, the solid product was dissolved into methanol $(10 \mathrm{~kg}$ methanol $\cdot \mathrm{kg}$ ectoine $\left.^{-1}\right)$ in a $16.4 \mathrm{~L}(H=0.3 \mathrm{~m} ; D=0.3 \mathrm{~m})$ CSTR operated at an HRT of $1 \mathrm{~h}$. An additional ultrafiltration $\left(1.1 \mathrm{~m}^{2}\right)$ step was included before ectoine crystallization to remove insoluble matter, especially the $\mathrm{Na}_{2} \mathrm{SO}_{4}$ produced during the previous neutralization step. Ectoine crystallization was performed in a 12.3 $\mathrm{L}(H=0.3 ; D=0.3 \mathrm{~m})$ CSTR operated at a HRT of $1 \mathrm{~h} .99 \%$ of the methanol was evaporated at $65^{\circ} \mathrm{C}$ with the use of low pressure steam $(2 \mathrm{bar})$ and subsequently recovered in a $3.6 \mathrm{~m}^{2}$ condenser using cooling water as the refrigerant $\left(15^{\circ} \mathrm{C}\right)$. The ectoine crystallized was then centrifuged to remove the remaining methanol. The final product was obtained after a second drying step in a $0.9 \mathrm{~m}^{2}$ tray dryer with warm air $\left(20^{\circ} \mathrm{C}\right)$.

Economic Analysis. The economic analysis was performed using as indicators the net present value evaluated at 20 years $\left(\mathrm{NPV}_{20}\right)$, the payback period (PP), and the internal rate of return (IRR). The $\mathrm{NPV}_{20}$ was calculated from the free cash flow (FCF) according to eq 9:

$$
\mathrm{NPV}_{20}=\sum_{t=0}^{t=20} \frac{\mathrm{FCF}_{t}}{(1+r)^{t}}
$$

where $t$ represents the financial period in years, and $r$ stands for the interest rate $(5 \%)$. For the calculation of FCF, the TIC were attributed to year 0 and a circulating capital over the TIC of $5 \%$ was included in year 1 . A linear depreciation of 20 years and a tax rate of $30 \%$ were selected for the calculation. A median selling price of $600 €$. $\mathrm{kg}$ ectoine ${ }^{-1}$ was used to estimate the $\mathrm{NPV}_{20}$. The IRR was calculated as the value of $r$ that makes $\mathrm{NPV}_{20}=0$. Finally, the PP was estimated as the first period in which the accumulated FCF is positive. The break-even price was used for estimating the ectoine production costs as the value of sales that guarantees a $\mathrm{NPV}_{20}$ equal to zero.

Capital Costs. TIC were calculated according to Lang's Method. This method is based on a series of factors for the estimation of the TIC from the sum of the individual prices of equipment (PEC). A Lang factor of 4.09 has been calculated as optimum for solid-liquid processes like the one evaluated in this paper (Table 1). ${ }^{33}$ Equipment prices were obtained from Matches' database, a commonly used

\begin{tabular}{|c|c|c|c|}
\hline & base case & $-25 \%$ & $25 \%$ \\
\hline equipment & 1.00 & 1.00 & 1.00 \\
\hline+ equipment installation labor ${ }^{a}$ & 0.38 & 0.29 & 0.48 \\
\hline+ instrumentation and controls & 0.12 & 0.12 & 0.12 \\
\hline+ piping & 0.31 & 0.31 & 0.31 \\
\hline + electrical installations & 0.10 & 0.10 & 0.10 \\
\hline+ buildings & 0.29 & 0.29 & 0.29 \\
\hline+ yard improvements ${ }^{a}$ & 0.10 & 0.08 & 0.13 \\
\hline + service facilities & 0.54 & 0.54 & 0.54 \\
\hline+ land & 0.06 & 0.06 & 0.06 \\
\hline direct plant cost & 2.90 & 2.78 & 3.02 \\
\hline+ engineering and supervision $^{a}$ & 0.32 & 0.24 & 0.40 \\
\hline+ construction expenses $^{a}$ & 0.34 & 0.26 & 0.43 \\
\hline direct and indirect costs & 3.56 & 3.28 & 3.85 \\
\hline+ contractor's fee & 0.18 & 0.16 & 0.19 \\
\hline+ contingency & 0.36 & 0.33 & 0.38 \\
\hline total depreciable costs(Lang Factor) & 4.09 & 3.77 & 4.42 \\
\hline
\end{tabular}
quotation tool that compiles order-of-magnitude estimations for more

Table 1. Influence of Labor Cost on the Lang Factor Calculation

${ }^{a}$ Wage dependent parameters. 
than 275 types of equipment. ${ }^{34}$ Matches' equipment prices were updated to $2020-€$ considering a dollar exchange rate of $1.09 € \cdot \$^{-1}$ and an accumulated dollar inflation rate of 1.1 in the period 20142020. Prices from equipment not included in Matches' database were obtained from quotations of national and international companies and literature review (Table S6).

Operational Costs. Operational costs were calculated as the sum of consumables (raw materials, chemical reagents, and utilities), transportation cost of raw materials and products, maintenance costs, labor costs, and wastewater treatment cost. Given the high geographical variability in commodity prices, Madrid (Spain) was selected as the model city for the estimation, presenting a worldwide average cost for energy and water selling prices (Table 2).

Table 2. Summary of Utility and Commodity Prices Used in Madrid as Model Country

\begin{tabular}{lcc}
\multicolumn{1}{c}{ consumable } & price & unit \\
energy & 0.10 & $€ \cdot \mathrm{kWh}^{-1}$ \\
water & 1.89 & $€ \cdot \mathrm{m}^{-3}$ \\
steam & 0.14 & $€ \cdot \mathrm{kg}^{-1}$ \\
cooling water & 0.00006 & $€ \cdot \mathrm{kg}^{-1}$ \\
distilled water & 0.07 & $€ \cdot \mathrm{kg}^{-1}$ \\
methanol & 2.00 & $€ \cdot \mathrm{kg}^{-1}$ \\
$\mathrm{H}_{2} \mathrm{SO}_{4} 98 \% \mathrm{w} \cdot \mathrm{w}^{-1}$ & 0.20 & $€ \cdot \mathrm{kg}^{-1}$ \\
$\mathrm{NaOH}_{\text {ion exchange resin }}{ }^{-1}$ & 0.46 & $€ \cdot \mathrm{kg}^{-1}$ \\
$\mathrm{HCl} 32 \% \mathrm{w}^{-1}$ & 342.57 & $€ \cdot \mathrm{kg}^{-1}$ \\
packing media & 0.25 & $€ \cdot \mathrm{kg}^{-1}$ \\
$\mathrm{NaCl}$ & 1.50 & $€ \cdot \mathrm{kg}^{-1}$ \\
$\mathrm{NaNO}$ & $€ \cdot \mathrm{kg}^{-1}$ \\
micronutrients & 0.07 & $€ \cdot \mathrm{kg}^{-1}$ \\
$a_{\text {Including treatment cost as hazardous waste. }}$ & $€ \cdot \mathrm{kg}^{-1}$
\end{tabular}

Consumables and commodities requirements (energy, water, steam, cooling water, reagents, and raw materials) were calculated according to mass and energy balances (Tables S1-S7; Figures S1-S3). Typical values for energy requirements in centrifuges $\left(1 \mathrm{kWh} \cdot \mathrm{m}^{-3}\right)$, mixers $\left(0.2 \mathrm{~kW} \cdot \mathrm{m}^{-3}\right)$, and electrodialysis $\left(7 \mathrm{kWh} \cdot \mathrm{m}^{-3}\right)$ were selected according to the literature. ${ }^{35-37}$ Energy requirements for pumps were calculated according to eq 10 , where $P_{\text {pump }}$ represents the power in $\mathrm{kW}, Q$ stands for the volumetric flow expressed in $\mathrm{m}^{3} \cdot \mathrm{s}^{-1}, \Delta P$ is the pressure drop in $\mathrm{kPa}$, and 0.7 is the electrical efficiency of pumps and compressors.

$$
P_{\text {pump }}=\frac{Q \cdot \Delta P}{0.7}
$$

Energy requirements for blowers and compressors were calculated according to eqs 11 and 12 , where $P_{\text {blower }}$ represents the power in $\mathrm{kW}$, $P_{\text {is }}$ stands for the isentropic power in $\mathrm{kW}, 0.7$ is the electrical blower efficiency, $\gamma$ is the adiabatic coefficient, $T_{\text {out }}$ refers to the gas isentropic outlet temperature, $T_{\text {in }}$ represents the gas inlet temperature, $P_{\mathrm{m}}$ is the gas molecular weight, and $Q$ stands for the inlet volumetric flow.

$$
\begin{aligned}
& P_{\text {blower }}=\frac{P_{\text {is }}}{0.7} \\
& P_{\text {is }}=2.31 \cdot \frac{\gamma}{\gamma-1} \cdot \frac{T_{\text {out }}-T_{\text {in }}}{P_{\mathrm{m}}} \cdot Q
\end{aligned}
$$

Transportation costs for raw materials and ectoine products were considered comparable to other petrochemical products $\left(60 € \cdot \mathrm{t}^{-1}\right)$. The cost of ectoine transportation was equally distributed between production and extraction costs. Yearly maintenance costs of $3.5 \%$ over the TIC were selected as recommended by industrial waste operators. To the best of the authors' knowledge, there is not a standard method for evaluating the labor cost of biogas upgrading processes integrated in larger facilities. Therefore, labor costs were evaluated assuming a total of 192 person-h.week ${ }^{-1}$, as recommended by industrial waste operators. Two full-time operators with $8 \mathrm{~h}$-shift during week days $\left(2\right.$ person $\cdot 1$ shift $\cdot 8 \mathrm{~h} \cdot \mathrm{shift}^{-1} \cdot 5 \mathrm{~d} \cdot$ week $^{-1}=80$ person-h.week ${ }^{-1}$ ) and 2 part-time operators during the evening and night shifts during the whole week $\left(2\right.$ person $\cdot 2$ shift ${ }^{-1} \cdot 4 \mathrm{~h} \cdot \mathrm{shift}^{-1} \cdot 7$ $\mathrm{d} \cdot$ week $^{-1}=112$ person-h$\cdot$ week $^{-1}$ ) were herein considered. A wage of $14.5 € \cdot$ person $-h^{-1}$ was considered as average salary in Madrid (Spain). ${ }^{38}$ Wastewater treatment costs were considered comparable to domestic wastewater $\left(0.2 € \cdot \mathrm{m}^{-3}\right)$ given the low organic load of these waste streams.

Sensitivity Analysis. A sensitivity analysis for the most relevant consumables and commodities was performed to validate the results of the techno-economic analysis and provide a reliable error margin. In this context, the selling prices of water and energy and the costs of reagents, labor, and transportation were increased and decreased by $25 \%$. The Lang Factor was calculated in each scenario assuming that some of the factors are wage-dependent (Table 2). PEC was also increased and decreased by $25 \%$ to assess the influence of the assumptions made in the equipment cost estimation. The worst- and best-case scenarios were calculated considering a $25 \%$ decrease/ increase in all the items at once. Additionally, a sensitivity analysis was performed on the interest rate $(5 \%, 10 \%$, and $20 \%)$ and the tax rate $(30 \%, 40 \%$, and $50 \%)$ to evaluate the robustness of the economic analysis.

\section{RESULTS AND DISCUSSION}

Capital Costs. The total PEC for ectoine production from biogas accounted for $1.03 \mathrm{M} €$, with $0.66 \mathrm{M} €$ and $0.37 \mathrm{M} €$ corresponding to the bioconversion of $\mathrm{CH}_{4}$-biogas into ectoine and to the ectoine extraction and purification, respectively. Surprisingly, the PEC of ectoine production represented $63.8 \%$ of the total PEC, while $36.2 \%$ was allocated to the downstream processing. The high PEC differences between ectoine production and downstream stages can be explained by the volumetric flow rates of gas $\left(67 \mathrm{~N} \mathrm{~m}^{3}\right.$ biogas $\cdot \mathrm{h}^{-1}$ and $280 \mathrm{~N} \mathrm{~m}^{3}$ air $\left.\cdot \mathrm{h}^{-1}\right)$ and liquid $\left(6 \mathrm{~m}^{3}\right.$ water $\left.\cdot \mathrm{h}^{-1}\right)$ streams processed at similar HRT, which incurred a great variability in equipment size. The application of the Lang's Method resulted in a TIC of 4.21 M€, with 2.69 M€ and 1.52 M€ for the ectoine production and downstream processing, respectively (Figure 2).

The commissioning of the $\mathrm{BCB}$, with an individual volume of $195 \mathrm{~m}^{3}$, represented the main equipment cost with $0.6 \mathrm{M} €$.

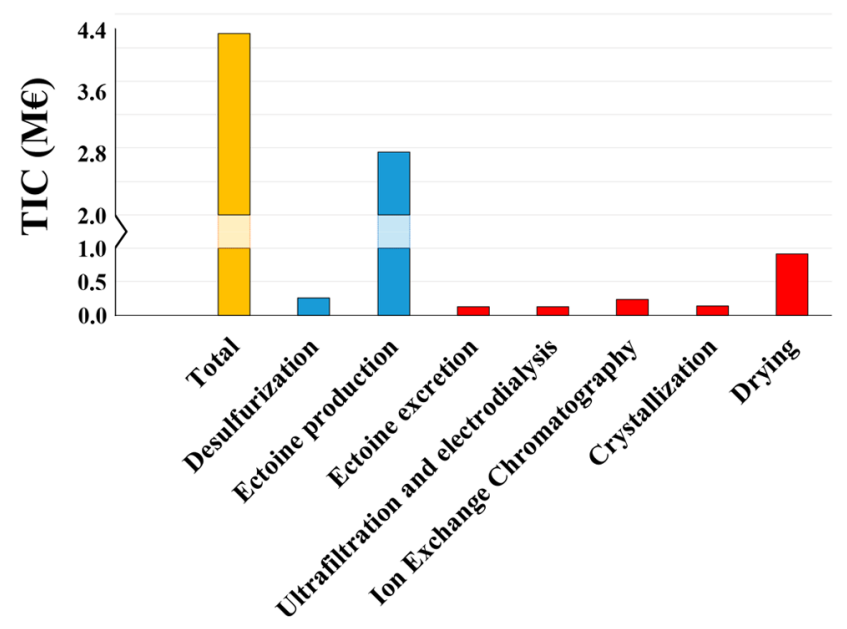

Figure 2. Total Investment Costs (TIC) of the biogas valorization into ectoine process. In yellow bars, the TIC of the process. In blue bars, the TIC of the different items for the ectoine production from biogas. In red bars, the TIC of the different items for the downstream processing of ectoine. 
The purchase of this bioreactor accounted for $56.8 \%$ of the total PEC. The elevated price of the BCB $\left(3000 € \cdot \mathrm{m}^{-3}\right)$ was due to the need for high-quality materials that resist the high corrosion induced by the high salinity of the mineral medium and the additional safety measures required for the ATEX application derived from mixing biogas and air. ${ }^{39}$ These results are in good agreement with previous techno-economic analyses studying the bioconversion of $\mathrm{CH}_{4}$ into $\mathrm{PHA}$, which identified BCBs as the most expensive pieces of equipment. ${ }^{5,40}$ The biotrickling filter dedicated to biogas desulfurization constituted the second most expensive equipment in the biogas bioconversion process with $53048 €$.

The equipment showing the highest PEC in the downstream processing stage were the drying units with $0.22 \mathrm{M} €$, accounting for $59.6 \%$ of the downstream PEC and $21.6 \%$ of the overall process PEC. Ectoine excretion, ultrafiltration, and electrodialysis, IEX, and crystallization represented $8.0 \%, 8.3 \%$, $8.9 \%$, and $15.2 \%$ over the total downstream PEC, respectively.

Operational Costs. The operational costs for biogas-based ectoine production accounted for $1.4 \mathrm{M} € \cdot \mathrm{y}^{-1}$, with $0.3 \mathrm{M€} \cdot \mathrm{y}^{-1}$ and $1.1 \mathrm{M} € \cdot \mathrm{y}^{-1}$ associated with ectoine production and purification, respectively. The purchase of consumables (chemicals, raw materials, and utilities) was the most significant operational cost $\left(0.9 \mathrm{M} € \cdot \mathrm{y}^{-1}\right)$, accounting for $65.7 \%$ of the total operational costs (Figure 3 ). The ion

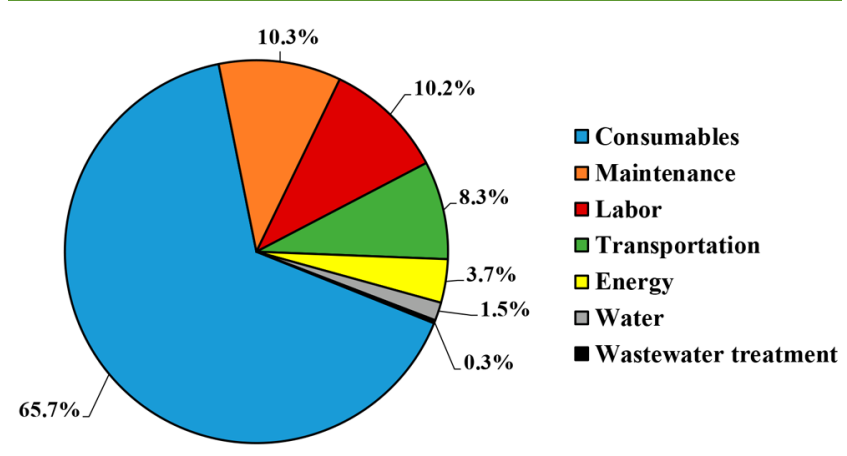

Figure 3. Individual share of the operational costs for ectoine production from biogas.

exchange resins for ectoine adsorption represented the highest raw material cost with $0.6 \mathrm{M} € \cdot \mathrm{y}^{-1}$, due to the use of expensive high performance resins $\left(343 € \cdot \mathrm{kg}^{-1}\right.$ ) and to their limited lifespan $(80 \mathrm{~d})$. In this context, the bulk purchase of this raw material $\left(1825 \mathrm{~kg} \cdot \mathrm{y}^{-1}\right)$ could help in reducing the effective selling price of ectoine. The ectoine retention performance was used as resin selection criteria in this study, while the maximum $\mathrm{NPV}_{20}$ might be achieved using resins with a lower performance but a longer lifespan.

Maintenance and labor costs represented the second and third largest operational cost, with $10.3 \%$ and $10.2 \%$ of the total cost share (Figure 3). Maintenance costs were herein calculated as $3.5 \%$ of TIC, and therefore the high PEC of the installation and in particular the elevated yearly maintenance of the $\mathrm{BCB}$, can explain the high contribution of maintenance costs.

In addition, transportation costs were identified as a nonnegligible operational cost, with $8.3 \%$ of the total operational costs (Figure 3). This can be explained by the high amount of mineral salts required for the growth of haloalkaliphilic methanotrophic bacteria (199.4 $\mathrm{t} \cdot \mathrm{y}^{-1}$ and $121.0 \mathrm{t} \cdot \mathrm{y}^{-1}$ of $\mathrm{NaCl}$ and $\mathrm{NaNO}_{3}$, respectively). However, this cost was marginal compared to those reported by Shazad and coworkers (2013) during the production of PHA from slaughter waste, which accounted for almost $50 \%$ of the total production costs. ${ }^{41}$ The transportation cost of products represented only $2.5 \%$ of the total transportation costs given the reduced amount of ectoine produced $\left(10.0 \mathrm{t} \cdot \mathrm{y}^{-1}\right)$. These results suggest that the use of in situ produced biogas as carbon source for bacterial fermentations entails a significant reduction in the bioproducts production costs. Notwithstanding, the influence of transportation costs on the final ectoine price should be taken into account in the design of next-generation biorefineries as it might be of relevance if the distance to mineral salts suppliers and potential ectoine buyers was significantly increased.

Finally, the costs of energy and water represented only $3.7 \%$ and $1.5 \%$ of the total operational costs, respectively. The relevance of these commodities might change significantly depending on the location of the plant and should not be neglected when studying the viability of future ectoine production plants. Wastewater treatment costs were negligible compared to the total operational costs, representing a share of only $0.3 \%$.

Economic Analysis. As a result of the process, $10 \mathrm{t} \cdot \mathrm{y}^{-1}$ of ectoine were obtained from $67 \mathrm{~N} \mathrm{~m}^{3} \mathrm{~h}^{-1}$ of biogas, which was in line with the estimated global ectoine demand ranging 10$20 \mathrm{t} \cdot \mathrm{y}^{-1}$. The calculations resulted in an overall ectoine productivity of $17 \mathrm{mg}$ ectoine produced $\cdot \mathrm{m}^{-3}$ biogas treated. A break-even price for ectoine, calculated as the selling price at which $\mathrm{NPV}_{20}$ becomes 0 , of $214 € \cdot \mathrm{kg}^{-1}$ was estimated. This value represented a 3 -fold decrease against the lowest reported market values for ectoine production with Halomonas Elongate (600-1000 $\left.€ \cdot \mathrm{kg}^{-1}\right)$. Interestingly, $66.6 \%$ of the break-even price was allocated to the operational costs, while the remaining $33.4 \%$ was attributed to the TIC and its amortization.

In view of the wide difference between the calculated ectoine production costs $\left(214 € \cdot \mathrm{kg}^{-1}\right)$ and the median ectoine market value $\left(600 € \cdot \mathrm{kg}^{-1}\right)$, an outstandingly positive $\mathrm{NPV}_{20}$ of $33.6 \mathrm{M}$ $€$ was obtained. Accordingly, a IRR of $70.4 \%$ and a PP of 1.5 year ( 2 years) were obtained. The high profitability of $\mathrm{CH}_{4}$-toectoine process has been previously reported by Cantera and co-workers in a preliminary techno-economic study for the coproduction of PHA, single cell protein, extracellular polysaccharides, and ectoine from $\mathrm{CH}_{4}$ diluted streams. ${ }^{36}$ In this regard, given the wide difference between production cost and current ectoine selling price, and the limited number of companies dedicated to the production of ectoine, it is worth questioning if ectoine is currently sold following a cost-based or a market-based strategy. If ectoine commercialization follows a cost-based strategy, then the production of ectoine from biogas using methanotrophic bacteria could have the potential to displace the current industrial routes with Halomonas Elongate. On the contrary, if ectoine is following a market-based strategy, the selling prices could drop in the future. In any scenario, the low production costs herein presented (3-6 times lower than the current selling price of ectoine) guarantee a current and future economic feasibility of the biogas-to-ectoine process.

In this context, the results indicated a high profitability of the valorization of biogas into ectoine regardless of the 20$30 \%$ level of estimation of techno-economic analysis like the one presented in this paper. Regardless of the low worldwide demand of ectoine, in the range of $20 \mathrm{t} \cdot \mathrm{y}^{-1}$, which could incur 


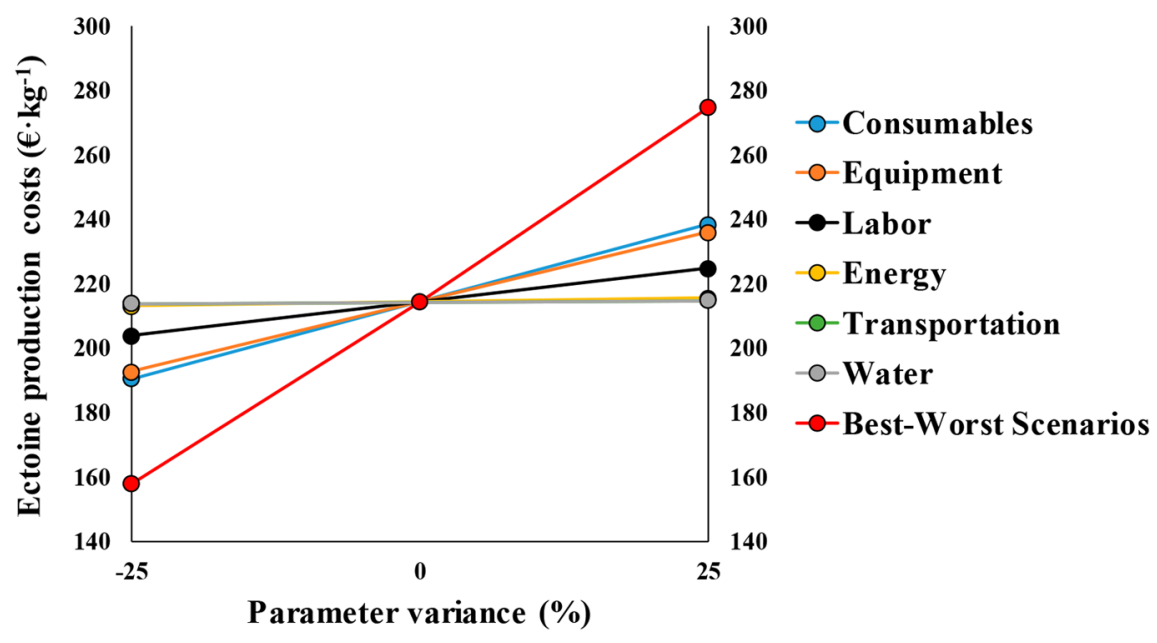

Figure 4. Sensitivity analysis of ectoine production costs toward the most relevant capital and operational costs. All the parameters were increased and decreased individually by $25 \%$.

in a limited impact of ectoine production from biogas at a global scale, these results demonstrate that bioproduct production with methanotrophic bacteria should not be restricted to bulk and low added-value products such as PHA, SCP, or methanol but also to fine chemicals such as ectoine. The results herein presented open the door to a great opportunity for waste management companies and biogas producers in general to invest in the production of high addedvalue products from biogas.

However, $\mathrm{CH}_{4}$ and $\mathrm{O}_{2}$ gas-liquid mass transfer, biomass concentration, and bacterial bioproduct productivity in aerated bioreactors have been identified as key factors determining the economic feasibility of bioprocesses. ${ }^{42}$ Thus, the influence of the economy of scale and the aforementioned biotechnological limitations on the final ectoine production costs should be evaluated in the future.

Sensitivity Analysis. A sensitivity analysis was herein performed to assess the impact of the assumptions made during the calculation of the operational and capital costs. In this context, the highest sensitivity of ectoine production costs was observed toward changes in the purchase price of consumables (chemicals, raw materials, and utilities). A $25 \%$ increase/decrease in the consumables purchase costs resulted in ectoine production costs ranging from 191 to $238 € \cdot \mathrm{kg}^{-1}$ (Figure 4).

The ectoine production costs also showed a high sensitivity toward the PEC estimation. A $\pm 25 \%$ variance in the PEC resulted in a $\pm 10.1 \%$ change in the production costs of ectoine (Figure 4). Interestingly, even if PEC increased by 1 order of magnitude (from 1.03 $\mathrm{M} €$ to $10.3 \mathrm{M} €$ ), the biogas-based ectoine would be still market-competitive with a break-even price of $991.7 € \cdot \mathrm{kg}^{-1}$.

The sensitivity analysis showed a mild influence of labor costs on the final product price, with ectoine production costs varying by $4.9 \%$ with a $25 \%$ change on the average wage. At this point it should be stressed that changes in labor costs increased operational costs by raising the average wage of plant operators from $10.9 € \cdot \mathrm{h}^{-1}$ to $18.1 € \cdot \mathrm{h}^{-1}$, but also entailed a change in the Lang Factor from 3.77 to 4.42 , thus affecting the TIC (Table 2). Despite the change in TIC from 4.2 M€ to 4.5 $\mathrm{M} €$, the ectoine production cost calculated was $225 € \cdot \mathrm{kg}^{-1}$.
Variations in energy and water purchase prices resulted in negligible changes in the ectoine production costs of 0.6 and $0.3 \%$, respectively. These results implied that ectoine production cost in waste treatment facilities might be profitable regardless of the variability of commodity prices. In contrast, recent techno-economic analyses indicated that the production of low added-value products such as biopolymers from biogas exhibited an inherently high influence of these commodities on the economic feasibility of the technology. ${ }^{5}$ Despite transportation costs represented a significant share of the total operational costs $(8.3 \%)$, a $25 \%$ change on the unitary transportation costs (from $60 € \cdot \mathrm{t}^{-1}$ to 45 and $75 € \cdot \mathrm{t}^{-1}$ ) induced negligible changes on the ectoine production costs from 213.8 to $214.8 € \cdot \mathrm{kg}^{-1}$. Interestingly, increasing transportation unitary costs by 1 order of magnitude (from 60 to $600 € \cdot \mathrm{t}^{-1}$ ) increased ectoine production costs to only $232.5 € \cdot \mathrm{kg}^{-1}$. These results showed a high robustness of the process toward changes on the most influential parameters for other low added-value bioproducts and expand the economic viability of ectoine production in waste treatment facilities to all sort of socioeconomic contexts in terms of commodities (water and energy) costs. The different cost sensitivity of low addedand high added-value bioproducts produced by methanotrophs in waste treatment plants enriches the current dissertation on the scientific community on the roadmap for future and successful $\mathrm{CH}_{4}$-biorefineries.

The worst and best case scenarios for ectoine production from biogas were calculated assuming a $25 \%$ increase/decrease in all the aforementioned parameters. The evaluation of $\mathrm{NPV}_{20}$ and IRR in the worst- and best-case scenarios showed a high variability ranging from 28.4 to $38.6 \mathrm{M} €$ and from 46.8 to $112.3 \%$, respectively. The calculated PP varied slightly with the $25 \%$ increase/decrease between 0.96 ( 1 year) and 2.35 (3 years). Finally, ectoine production costs ranging from 158 to $275 € \cdot \mathrm{kg}^{-1}$ were estimated in the best and worst case scenarios.

Variations in the interest rate $(r)$ from $5 \%$ to $10 \%$ and $15 \%$ resulted in ectoine production costs of 214,238 , and $264 €$. $\mathrm{kg}^{-1}$, respectively. This increase in the ectoine production costs was correlated to the increase in the fixed and amortization costs of ectoine from $72 € \cdot \mathrm{kg}^{-1}$ to $95 € \cdot \mathrm{kg}^{-1}$ and $121 € \cdot \mathrm{kg}^{-1}$ for $r$ values of $5 \%, 10 \%$, and $15 \%$, respectively (Figure $5 \mathrm{~A}$ ). The operational costs were not affected by the variation of $r$, with a 
- Operational Cost - - -Fixed Cost and Amortization - - -Production Costs
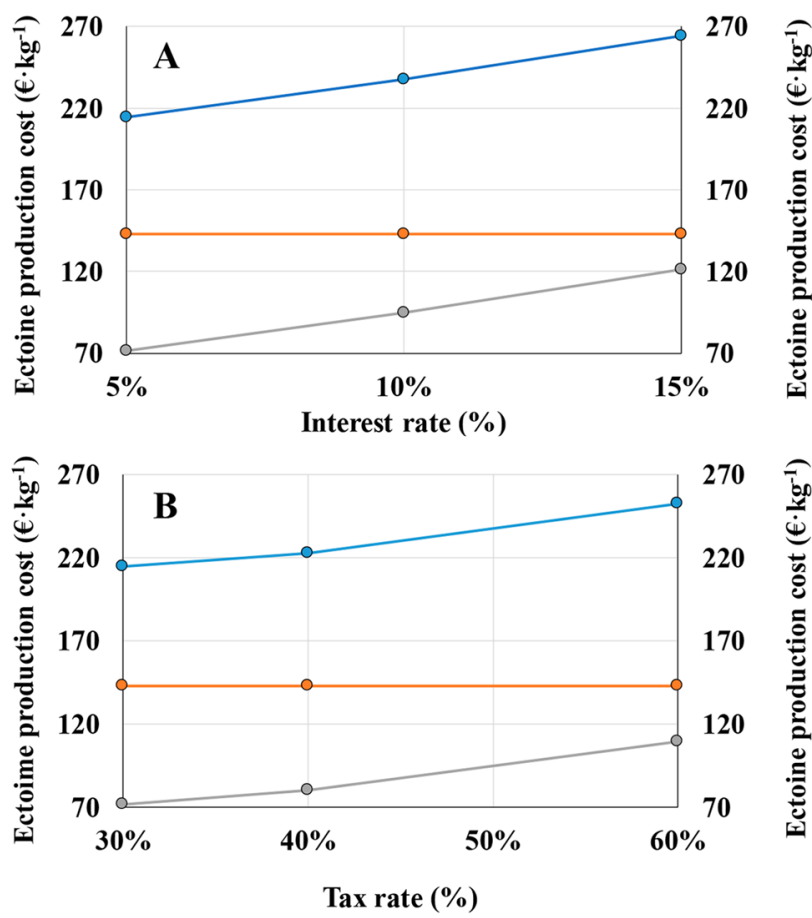

Figure 5. Sensitivity analysis of ectoine production costs toward changes in (A) interest rate, (B) tax rate.

constant value of $143 € \cdot \mathrm{kg}^{-1}$. Besides the increase of the fixed and amortization costs, the high margin between ectoine production costs and selling price, resulted in very positive $\mathrm{NPV}_{20}$ values in all the scenarios studied, with $33.6 \mathrm{M} €$ at $r=$ $5 \%, 21.6 \mathrm{M} €$ at $r=10 \%$, and $14.7 \mathrm{M} €$ at $r=15 \%$. The PP observed in all the scenarios studied remained below 2 years, with $1.5,1.6$, and 1.8 years for $r$ values of $5 \%, 10 \%$ and $15 \%$, respectively.

Similarly, an increase in the tax rate from $30 \%$ to $40 \%$ and $60 \%$ resulted in an increase of the ectoine production costs from $214 € \cdot \mathrm{kg}^{-1}$ to $223 € \cdot \mathrm{kg}^{-1}$ and $252 € \cdot \mathrm{kg}^{-1}$, respectively (Figure 5B). In this case, a fixed cost and amortization of 72 , 80 , and $110 € \cdot \mathrm{kg}^{-1}$ and $\mathrm{NPV}_{20}$ values of $33.6 \mathrm{M} €, 28 \mathrm{M} €$, and $17.3 \mathrm{M} €$ were calculated for tax rates of $30 \%, 40 \%$, and $60 \%$, respectively. Besides the changes in the ectoine production costs and the decrease of $\mathrm{NPV}_{20}$, high IRR of $70 \%, 60 \%$, and $40 \%$ were obtained for tax rates of $30 \%, 40 \%$, and $60 \%$, respectively. In addition, the PP calculated remained below 3 years in all the scenarios studied, with $1.5,1.8$, and 2.8 , for tax rates of $30 \%, 40 \%$, and $60 \%$, respectively. These results point to an outstanding process economic robustness of the biogas bioconversion into ectoine herein studied.

To the best of the authors' knowledge, these results represent the lowest reported value for ectoine production at large scale and constitute a proof-of-concept of the key role of biogas as a low-cost substrate in the future of next-generation biorefineries.

\section{CONCLUSIONS}

This work constituted the first techno-economic study of the large-scale production of ectoine from biogas in waste treatment plants. The results indicated a high profitability of the process with a payback time below 3 years in all the scenarios evaluated. Ectoine break-even prices in the best and worst case scenarios considered entailed a 3- to 6-fold decrease in the ectoine production costs when compared to the current production via long-time fermentation with Halomonas elongate, mainly due to the use of $\mathrm{CH}_{4}$-biogas as a low-cost carbon substrate for the growth of haloalkaliphilic bacteria. The process showed a high sensitivity toward the purchase cost of equipment and consumables (chemical reagents, raw materials, and utilities). On the contrary, the sensitivity analysis revealed a high robustness toward changes on water and energy prices, labor, and transportation costs. In summary, this study demonstrated that large-scale production of high added-value products from biogas represents a highly profitable alternative to the current utilization of biogas as energy source, but also a much more feasible valorization pathway than the production of low added-value bioproducts. However, the influence of certain techno-economic aspects such as the economy of scale or the microbial bioconversion yields of methane into ectoine on the development of future costeffective biogas biorefineries must be further investigated.

\section{ASSOCIATED CONTENT}

\section{SI Supporting Information}

The Supporting Information is available free of charge at https://pubs.acs.org/doi/10.1021/acssuschemeng.1c06772.

Figures S1-S3, Detailed process flow diagram of the biogas bioconversion into ectoine; Table S1, stream table of the biogas bioconversion into ectoine process; Table S2, global mass balance of the ectoine biosynthesis from biogas; Table S3, global mass balance of the ectoine extraction and purification; Table S4, elemental mass balance of the ectoine biosynthesis from biogas; Table S5, elemental mass balance of the ectoine extraction and purification; Table S6, summary of the purchased equipment cost and total investment cost; Table S7, summary of the individual equipment energy and power consumption; and a list of the equations used in the design and dimensioning of the equipment (PDF)

\section{AUTHOR INFORMATION}

\section{Corresponding Author}

Raúl Muñoz - Institute of Sustainable Processes, University of Valladolid, 47011 Valladolid, Spain; Department of Chemical Engineering and Environmental Technology, School of Industrial Engineering, University of Valladolid, 47011 Valladolid, Spain; (1) orcid.org/0000-0003-1207-6275; Email: mutora@iq.uva

\section{Authors}

Víctor Pérez - Institute of Sustainable Processes, University of Valladolid, 47011 Valladolid, Spain; Department of Chemical Engineering and Environmental Technology, School of Industrial Engineering, University of Valladolid, 47011 Valladolid, Spain; (1) orcid.org/0000-0002-7913-3740

Jose Luis Moltó - Activatec Ltd, Biocity, NG11GF Nottingham, United Kingdom

Raquel Lebrero - Institute of Sustainable Processes, University of Valladolid, 47011 Valladolid, Spain; Department of Chemical Engineering and Environmental Technology, School of Industrial Engineering, University of Valladolid, 47011 Valladolid, Spain

Complete contact information is available at: 
https://pubs.acs.org/10.1021/acssuschemeng.1c06772

\section{Author Contributions}

V.P.: Data curation, Investigation, methodology, visualization, and writing-original draft. J.L.M.: Investigation, methodology, and writing-review and editing. R.L.: Funding acquisition, methodology, supervision, and writing-review and editing. R.M.: Funding acquisition, methodology, supervision, and writing - review and editing.

\section{Notes}

The authors declare no competing financial interest.

\section{ACKNOWLEDGMENTS}

This publication is part of the project DEEP PURPLE, which has received funding from the Bio Based Industries Joint Undertaking under the European Union's Horizon 2020 research and innovation programme under grant agreement $N^{\circ}$ 837998. This work was also supported by the regional government of Castile and Leon and the EU-FEDER programme (CLU 2017-09, UIC 315). V.P. wants to specially thank the regional government of Castile and Leon and the University of Valladolid for his PhD contract (C18IPJCL).

\section{ABBREVIATIONS}

$\mathrm{BCB}$; bubble column bioreactor; $\mathrm{BV}$; bed volume; $\mathrm{CHP}$; combined heat and power; $\mathrm{D}$; equipment diameter; EBRT; empty bed residence time; EC; elimination capacity; FCF; free cash flow; $H$; equipment height; HRT; hydraulic retention time; IEX; ion exchange chromatography; IRR; internal rate of return; $\mathrm{NPV}_{20}$; net present value; PEC; purchased equipment cost; PHA; polyhydroxyalkanoate; PP; payback period; RE; removal efficiency; TIC; total investment costs

\section{REFERENCES}

(1) EBA. Statistical Report of the European Biogas Association 2020. European Biogas Association: Belgium, 2021.

(2) Kaparaju, P.; Rintala, J. Generation of heat and power from biogas for stationary applications: boilers, gas engines and turbines, combined heat and power (CHP) plants and fuel cells. In The Biogas Handbook, Science, Production, and Applications; Wellinger, A., Murphy, J., Baxter, D., Eds.; Woodhead Publishing: Cambridge, 2013; pp 404-427 DOI: 10.1533/9780857097415.3.404.

(3) IRENA. Renewable power generation costs in 2018. International Renewable Energy Agency: Abu Dhabi, 2019; pp 11-30.

(4) IRENA. Renewable power generation costs in 2019. International Renewable Energy Agency; Abu Dhabi, 2020, pp 18-43.

(5) Pérez, V.; Mota, C. R.; Muñoz, R.; Lebrero, R. Polyhydroxyalkanoates (PHA) production from biogas in waste treatment facilities: Assessing the potential impacts on economy, environment and society. Chemosphere 2020, 255, 126929.

(6) Pieja, A. J.; Morse, M. C.; Cal, A. J. Methane to bioproducts: the future of the bioeconomy? Curr. Opin. Chem. Biol. 2017, 41, 123-131.

(7) Cantera, S.; Sánchez-Andrea, I.; Lebrero, R.; García-Encina, P. A.; Stams, A. J. M.; Muñoz, R. Multi-production of high added market value metabolites from diluted methane emissions via methanotrophic extremophiles. Bioresour. Technol. 2018, 267, 401-407.

(8) European Commission. Circular economy action plan: for a cleaner and more competitive Europe. European Commission: Luxembourg, 2020 DOI: 10.2779/05068.

(9) Pérez, V.; Lebrero, R.; Muñoz, R. Comparative evaluation of biogas valorization into electricity/heat and poly(hydroxyalkanoates) in waste treatment plants: assessing the influence of local commodity prices and current biotechnological limitations. ACS Sustainable Chem. Eng. 2020, 8 (20), 7701-7709.
(10) Toledo-Cervantes, A.; Estrada, J. M.; Lebrero, R.; Muñoz, R. A comparative analysis of biogas upgrading technologies: photosynthetic vs physical/chemical processes. Algal Res. 2017, 25, 237-243.

(11) Strong, P. J.; Kalyuzhnaya, M.; Silverman, J.; Clarke, W. P. A methanotroph-based biorefinery: Potential scenarios for generating multiple products from a single fermentation. Bioresour. Technol. 2016, 215, 314-323.

(12) López, J. C.; Rodríguez, Y.; Pérez, V.; Lebrero, R.; Muñoz, R. $\mathrm{CH}_{4}$-based polyhydroxyalkanoate production: a step further towards a sustainable bioeconomy. In Biotechnological Applications of Polyhydroxyalkanoates; Kalia, V. C., Eds.; Springer: Singapore, 2019; pp 283-321 DOI: 10.1007/978-981-13-3759-8 11.

(13) Khmelenina, V. N.; Rozova, O. N.; But, S. Y.; Mustakhimov, I. I.; Reshetnikov, A. S.; Beschastnyi, A. P.; Trotsenko, Y. A. Biosynthesis of secondary metabolites in methanotrophs: biochemical and genetic aspects (review). Appl. Biochem. Microbiol. 2015, 51, $150-158$.

(14) Cantera, S.; Phandanouvong-Lozano, V.; Pascual, C.; GarcíaEncina, P. A.; Lebrero, R.; Hay, A.; Muñoz, R. A systematic comparison of ectoine production from upgraded biogas using Methylomicrobium alcaliphilum and a mixed haloalkaliphilic consortium. Waste Manage. 2020, 102, 773-781.

(15) Strong, P. J.; Xie, S.; Clarke, W. P. Methane as a resource: can the methanotrophs add value? Environ. Sci. Technol. 2015, 49 (7), 4001-4018.

(16) Becker, J.; Wittmann, C. Microbial production of extremolytes - high-value active ingredients for nutrition, health care, and wellbeing. Curr. Opin. Biotechnol. 2020, 65, 118-128.

(17) Pastor, J. M.; Salvador, M.; Argandoña, M.; Bernal, V.; ReinaBueno, M.; Csonka, L. N.; Iborra, J. L.; Vargas, C.; Nieto, J. J.; Cánovas, M. Ectoines in cell stress protection: Uses and biotechnological production. Biotechnol. Adv. 2010, 28 (6), 782-801.

(18) Chen, R.; Zhu, L.; Lv, L.; Yao, S.; Li, B.; Qian, J. Optimization of the extraction and purification of the compatible solute ectoine from Halomonas elongate in the laboratory experiment of a commercial production project. World J. Microbiol. Biotechnol. 2017, 33 (6), 116

(19) Muñoz, R.; Meier, L.; Diaz, I.; Jeison, D. A review on the stateof-the-art of physical/chemical and biological technologies for biogas upgrading. Rev. Environ. Sci. Bio/Technol. 2015, 14, 727-759.

(20) Lebrero, R.; Toledo-Cervantes, A.; Muñoz, R.; del Nery, V.; Foresti, E. Biogas upgrading from vinasse digesters: a comparison between an anoxic biotrickling filter and an algal-bacterial photobioreactor. J. Chem. Technol. Biotechnol. 2016, 91 (9), 2488-2495.

(21) Almenglo, F.; Ramírez, M.; Gómez, J. M.; Cantero, D. Operational conditions for start-up and nitrate-feeding in an anoxic biotrickling filtration process at pilot scale. Chem. Eng. J. 2016, 285, 83-91.

(22) Pérez, R.; Cantera, S.; Bordel, S.; García-Encina, P. A.; Muñoz, R. The effect of temperature during culture enrichment on methanotrophic polyhydroxyalkanoate production. Int. Biodeterior. Biodegrad. 2019, 140, 144-151.

(23) Carmona-Martínez, A.; Marcos-Rodrigo, E.; Bordel, S.; Marín, D.; Herrero-Lobo, R.; García-Encina, P. A.; Muñoz, R. Elucidating the key environmental parameters during the production of ectoines from biogas by mixed methanotrophic consortia. J. Environ. Manage. 2021, 298, 113462.

(24) Cantera, S.; Lebrero, R.; Rodríguez, E.; García-Encina, P. A.; Muñoz, R. Continuous abatement of methane coupled with ectoine production by Methylomicrobium alcaliphilum $20 \mathrm{Z}$ in stirred tank reactors: A step further towards greenhouse gas biorefineries. $J$. Cleaner Prod. 2017, 152, 134-141.

(25) Akberdin, I. R.; Thompson, M.; Hamilton, R.; Desai, N.; Alexander, D.; Henard, C. A.; Guarnieri, M. T.; Kalyuzhnaya, M. G. Methane utilization in Methylomicrobium alcaliphilum $20 Z^{\mathrm{R}}$ : a systems approach. Sci. Rep. 2018, 8 (1), 2512.

(26) Lanzatech. https://www.lanzatech.com/ (accessed 11/20/ 2021). 
(27) Muñoz, R.; Soto, C.; Zúñiga, C.; Revah, S. A systematic comparison of two empirical gas-liquid mass transfer determination methodologies to characterize methane biodegradation in stirred tank bioreactors. J. Environ. Manage. 2018, 217, 247-252.

(28) Yu, Y.; Ramsay, J. A.; Ramsay, B. A. On-line estimation of dissolved methane concentration during methanotrophic fermentations. Biotechnol. Bioeng. 2006, 95 (5), 788-793.

(29) Cantera, A.; Lebrero, R.; Rodríguez, S.; García-Encina, P. A.; Muñoz, R. Ectoine bio-milking in methanotrophs: A step further towards methane-based bio-refineries into high added-value products. Chem. Eng. J. 2017, 328, 44-48.

(30) Rodero, M. R.; Muñoz, R. Personal communication, 2021 (unpublished results).

(31) Fülberth, K.; Müssig, H.; Wesp, B. WO2003055862A1, 2002, Method for the chromatographic isolation of ectoine.

(32) Sauer, T.; Galinski, E. A. Bacterial milking: a novel bioprocess for production of compatible solutes. Biotechnol. Bioeng. 1998, 59 (1), 128.

(33) Ulrich, G. D.; Vasudevan, P. T. Chapter 5: Capital Cost Estimation. In Chemical Engineering, Process Design and Economics: A Practical Guide; Ulrich, G. D., Vasudevan, P. T., Eds.; Process Publishing: Durham, 2006; pp 331-408.

(34) Matches. Matches' Process Equipment Cost Estimates. https:// www.matche.com/equipcost/Default.html (accessed 11/20/2021).

(35) Turek, M. Cost effective electrodialytic seawater desalination. Desalination 2003, 153 (1), 371-376.

(36) Cantera, S.; Muñoz, R.; Lebrero, R.; López, J. C.; Rodríguez, T.; García-Encina, P. A. Technologies for the bioconversion of methane into more valuable products. Curr. Opin. Biotechnol. 2018, 50, 128-135.

(37) Szepessy, S.; Thorwid, P. Low energy consumption of highspeed centrifuges. Chem. Eng. Technol. 2018, 41 (12), 2375-2384.

(38) worlddata.info. Average income around the world. https:// www.worlddata.info/average-income.php (accessed 11/20/2021).

(39) Humbird, D.; Davis, R.; McMillan, J.D. Aeration costs in stirred-tank and bubble column bioreactors. Biochem. Eng. J. 2017, 127, $161-166$.

(40) Levett, I.; Birkett, G.; Davies, N.; Bell, A.; Langford, A.; Laycock, B.; Lant, P.; Pratt, S. Techno-economic assessment of poly3-hydroxybutyrate (PHB) production from methane - The case for termophilic bioprocessing. J. Environ. Chem. Eng. 2016, 4 (4A), 3724-3733.

(41) Shahzad, K.; Kettl, K.-H.; Titz, M.; Koller, M.; Schnitzer, H.; Narodoslawsky, M. Comparison of ecological footprint for biobased PHA production from animal residues utilizing different energy sources. Clean Technol. Environ. Policy 2013, 15, 525-536.

(42) Choi, J.; Lee, S. Y. Factors affecting the economics of polyhydroxyalkanoate production by bacterial fermentation. Appl. Microbiol. Biotechnol. 1999, 51, 13-21.

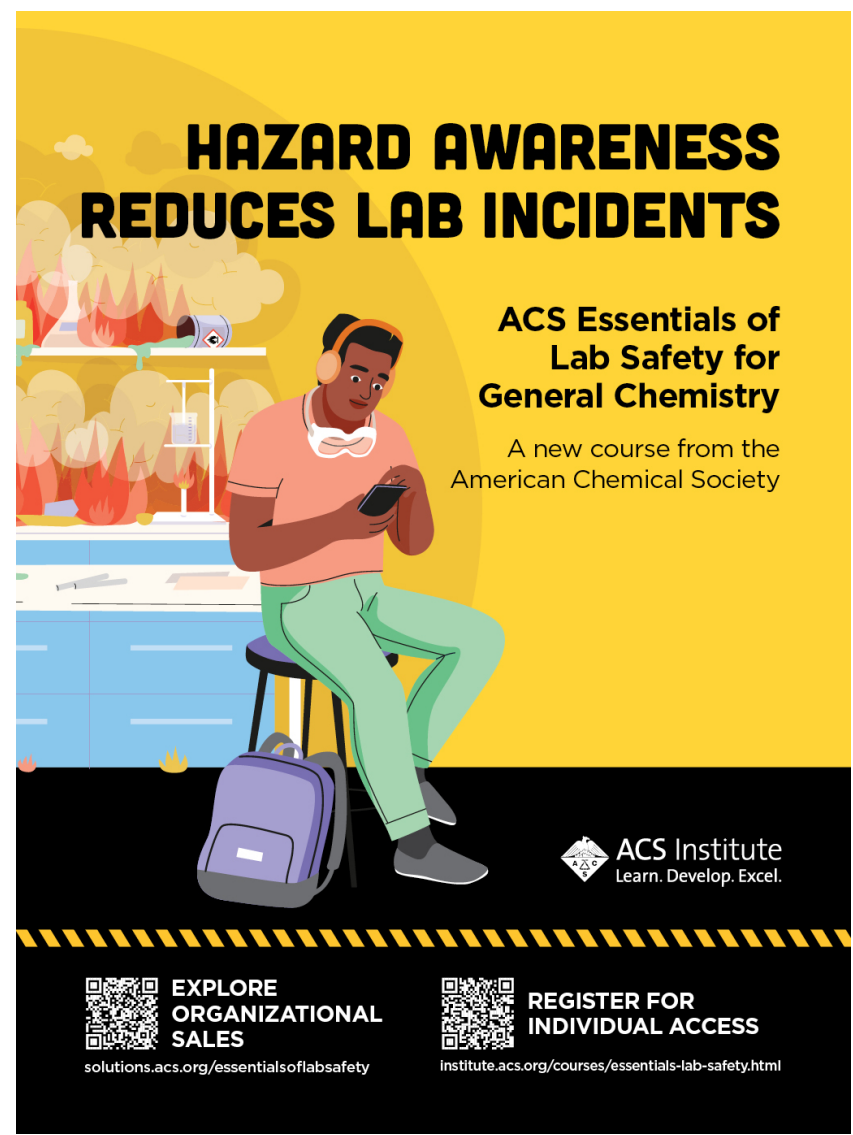

